\title{
Wirtualizacja działań społecznych i obywatelskich - szanse i zagrożenia - na przykładzie Kongresu osób z niepełnosprawnościami
}

Zbigniew Głąb (D) https://orcid.org/0000-0003-2017-0915 Uniwersytet Łódzki 


\title{
Streszczenie
}

Ograniczenie bezpośrednich kontaktów, wynikające z pandemii COVID-19, sprawiło, że wiele przedsięwzięć - chcąc zachować swoją ciągłość - przeniosło się do internetu. Jednym z nich jest Kongres osób z niepełnosprawnościami - cykliczna inicjatywa społeczna angażująca i łącząca osoby oraz instytucje związane z tematyką niepełnosprawności - nastawiona na wprowadzanie zmian i nowych rozwiązań w tym obszarze.

Celem badania było określenie, w jaki sposób Kongres zmienił swój charakter na skutek przeniesienia go do sieci, a także jakie są z tym związane nowe szanse, wyzwania i zagrożenia.

$\mathrm{W}$ analizie przyjęto perspektywę ruchu społecznego z uwzględnieniem trudności w zastosowaniu tej teorii w odniesieniu do środowiska niepełnosprawnościowego.

Na potrzebę analizy zostało przeprowadzonych 8 wywiadów swobodnych ukierunkowanych z organizatorami Kongresu i towarzyszących mu konwentów - będących ekspertami w dziedzinie niepełnosprawności, zaangażowanymi w organizację Kongresu osób z niepełnosprawnościami w 2020 r. Wyniki badań wskazują na odczuwalną zmianę charakteru kongresu - szczególnie związaną z aspektem społecznym, odnoszącym się do relacji i więzi pomiędzy uczestnikami. Wśród najważniejszych obaw znalazła się troska o utrzymanie rangi Kongresu jako wydarzenia wyróżniającego się i przyciągającego nowe osoby do kształtującego się zalążka reprezentacji osób z niepełnosprawnościami w Polsce. Do szczególnie podkreślanych zalet wirtualizacji należy natomiast zaliczyć wyrównywanie dostępności dla osób z różnymi niepełnosprawnościami.

\section{Słowa kluczowe}

Kongres osób z niepełnosprawnościami, ruch społeczny, środowisko niepełnosprawnościowe, wirtualizacja.

\section{Virtualization of social and civic activities - opportunities and threats - on the example of the Congress of People with Disabilities}

\begin{abstract}
The limitation of direct contacts resulting from the COVID-19 pandemic caused many projects - wanting to maintain their continuity - to move to the Internet. One of them is the Congress of People with Disabilities - a cyclical social initiative involving and connecting people and institutions related to the subject of disability - aimed at introducing changes and new solutions in this area. The study aimed to determine how the Congress changed its nature as a result of its transfer to the Web, as well as the opportunities, challenges and threats associated with it.

The analysis takes the perspective of the social movement and the related issue of representation - taking into account the difficulties in applying this theory to the disability community in general. For the analysis, 8 free directed interviews were conducted with the organizers of the Congress and the accompanying conventions - experts (with and without disabilities) in the field of disability, involved in the organization of Congress 2020.

The research results indicate a noticeable change in the nature of the Congress - especially to the social aspect associated with the relations and bonds between participants. Among the most important concerns was maintaining the rank of the Congress as an event that stands out and attracts new people to the emerging nucleus of the representation of people with disabilities in Poland. The particularly emphasized advantages of virtualization include the equalization of accessibility for people with various disabilities.
\end{abstract}

\section{Keywords}

Congress of People with Disabilities, disability community, social movement, virtualization. 
Tongres osób z niepełnosprawnościami to oddolna inicjatywa społeczna mająca na Lcelu propagowanie idei zawartych w Konwencji o prawach osób z niepełnosprawnościami (KPON), w tym w szczególności idei niezależnego życia i niedyskryminacji osób $\mathrm{z}$ niepełnosprawnościami.

Kongres jest wydarzeniem cyklicznym odbywającym się raz do roku (w 2020 r. po raz szósty), stanowiącym całość wraz z towarzyszącymi mu regionalnymi konwentami w różnych miastach Polski. Kongres jest spotkaniem różnych środowisk niepełnosprawnościowych, które chcą wpływać na polityki publiczne związane z niepełnosprawnością i dążą do zmiany mającej na celu włączanie osób z niepełnosprawnościami w główny nurt życia społecznego. Co roku tematyka Kongresu jest nieco inna - nawiązuje ona również do bieżących wydarzeń (tematem przewodnim VI Kongresu osób z niepełnosprawnościami było życie niepełnosprawnych w trakcie pandemii COVID-19). Konwenty regionalne skupiają się zazwyczaj na lokalnych kwestiach związanych z sytuacją osób z niepełnosprawnościami, nie unikają jednak tematów ogólnych, dotyczących całego środowiska.

Coroczne spotkanie kongresu kończy się wypracowaniem uchwał i postulatów (również na konwentach regionalnych), które następnie kierowane są do wiadomości decydentów, mających bezpośredni wpływ na polityki publiczne (zarówno na poziomie rządowym, jak i samorządowym). W trakcie trzeciego Kongresu, zorganizowanego pod hasłem „Za niezależnym życiem”, wypracowano „Założenia dla projektów ustaw dla Nowego Systemu Wsparcia osób z niepełnosprawnościami” (Kongres III, 2017), które stały się swojego rodzaju manifestem programowym Kongresu. Propozycje zawarte w „Założeniach" pozwoliły na ukierunkowanie działań środowiska związanych z lobbingiem, a niektóre z nich są dyskutowane na poziomie ustawodawczym.

Kongres nie został sformalizowany, tworzą go liderzy - osoby indywidualne i organizacje pozarządowe, które w trybie doraźnym organizują wydarzenia kongresowe. Pomimo że Kongres odbywa się raz do roku, przygotowania i dyskusje z nim związane zajmują znaczną część roku, a wypracowanie „Założeń” prowadzone było w trybie pracy ciągłej. W podobnym trybie odbywa się transfer idei kongresowych do sfer rządowych i samorządowych, przejawiające się w udziale osób związanych z Kongresem w spotkaniach, seminariach, konferencjach, pracach koncepcyjnych czy też pisaniu artykułów popularnych i naukowych.

Kongres nie ma władz. Istnieje rada Kongresu, będąca nieformalnym ciałem odpowiedzialnym za sprawy merytoryczne i organizacyjne (nie jest ona przedstawicielstwem organizacji, a raczej grupą liderów). Patronem Kongresu jest Rzecznik Praw Obywatelskich. Kongres jest otwarty dla wszystkich, nie wymaga „zapisywania się” (przyjmowane są jedynie zgłoszenia do udziału w kongresie i konwentach - związane organizacją imprezy), nie ma stałego finansowania (Kongres przeprowadzany jest ze środków asygnowanych przez organizacje pozarządowe, zaś infrastruktura udostępniana jest niekiedy bezpłatnie przez instytucje administracji publicznej).

Kongres i konwenty do 2019 r. włącznie odbywały się w formie stacjonarnej - kongres w Warszawie, konwenty w większych miastach Polski. Na kongresie głównym oprócz 
sesji plenarnej odbywały się spotkania w panelach dyskusyjnych. W 2020 r. na skutek pandemii COVID-19 zdecydowano na przeniesienie działań do sieci (jedynie 2 z 7 konwentów odbyły się częściowo w formie stacjonarnej).

\section{RAMA TEORETYCZNA, METODA I CEL}

W badaniu przyjęto perspektywę ruchu społecznego jako pewnej formy działań zbiorowych, prowadzonych poza sferą instytucjonalną, nastawionej na zaspokajanie potrzeb kolektywnych przez realizację wspólnego celu (Ekstowicz, 2015, s. 44; Nowak, 2012, s. 4; Nowosielski, 2011, s. 5, 10; Paleczny, 2010, s. 11). Należy jednak już na wstępie zastrzec, że spojrzenie na Kongres przez pryzmat teorii ruchu społecznego jest pierwszą tego typu próbą i w dużej mierze skupia się na poszukiwaniu odpowiedzi na pytanie, czy Kongres definicyjnie mieści się w tej kategorii.

Jednocześnie należy zauważyć, że badanie zostało oparte na wywiadach z liderami, zaangażowanymi w organizację Kongresu w 2020 r. Jakkolwiek jest to istotna grupa z punktu widzenia działania ruchu społecznego, to jednak nie może być traktowana jako jego wyłączna determinanta (por. Malendowicz, 2016, s. 9), co oznacza że status Kongresu wymaga dalszych pogłębionych badań.

Głównym celem badania była analiza sytuacji Kongresu w obliczu konieczności przejścia do sieci i prowadzenia znakomitej części swojej działalności w środowisku wirtualnym. Czym jest Kongres i jak zmieniło się jego oblicze na skutek wirtualizacji, jej zalety i wady, zmiany jakościowe, jakie wywołało przeniesienie do sieci, a wreszcie przyszłość Kongresu - to wątki najsilniej eksponowane w przeprowadzonych wywiadach. Celem dodatkowym była wspomniana analiza Kongresu pod kątem funkcjonowania jako ruchu społecznego - z uwzględnieniem roli internetu w omawianym zjawisku. W prezentowanym artykule została ona przedstawiona po części związanej z analizą wywiadów jako podsumowanie i uzupełnienie rozważań dotyczących wirtualizacji Kongresu.

Wywiady miały charakter swobodny ukierunkowany (por. Konecki, 2000, s. 8). Zostały przeprowadzone w ciągu dwóch tygodni po VI Kongresie, który odbył się 24.10.2020 r. Kongres poprzedzony był przez konwenty. Wzięły w nich udział osoby zaangażowane - często od samego początku - w działalność Kongresu (warunkiem zakwalifikowania do wywiadu był udział w organizacji kongresu i/lub konwentów 2020). W grupie tej znalazły się osoby z i bez niepełnosprawności będące aktywnymi rzecznikami środowiska na różnych polach, na co dzień działające w ramach organizacji pozarządowych lub samodzielnie.

Dobór respondentów oparty ostał na dwóch założeniach. Pierwszym była porównywalna ranga badanych osób, zaangażowanych w organizację i koordynację kongresu lub jednego z konwentów. Drugim założeniem był udział w organizacji wirtualnych działań kongresu i konwentów w 2020 r. Założenia te spowodowały ograniczenie liczby badanych osób do 8 (pominięci zostali liderzy, którzy w 2020 r. nie brali udziału w organizacji lub brali w niewielkim zakresie, a tym samym nie mieli doświadczenia działania w warunkach wirtualnych). Średnia długość wywiadu wyniosła 30 minut (przedział 23-40 
minut na wywiad), co dało w sumie nieco ponad 240 minut nagrania. Materiał należy traktować jako pilotażowy i wyjściowy do dalszych rozszerzonych badań.

W prezentacji badań zastosowano anonimizację - poszczególne osoby zostały oznaczone symbolami W1-W8. Dodatkowym zabiegiem jest też unikanie podawania konkretnych nazw miast, w których odbywały się konwenty ze względu na możliwość łatwego powiązania z nimi konkretnych organizatorów.

\section{PERSPEKTYWA RUCHU SPOŁECZNEGO}

Ruch społeczny łączy ze sobą z jednej strony uświadamiane i racjonalne formy aktywności grupowej, z drugiej zachowania spontaniczne i emocjonalne tłumu. Działalność ruchów osadzona jest w obywatelskiej przestrzeni społecznej, opiera się na aktywności jednostek mających na celu zbiorowy interes, kreując postawy altruistyczne i mobilizując jednostki do wspólnego działania (Paleczny, 2010, s. 12). Ruchy społeczne wchodzą w obszar polityki pozainstytucjonalnej. W społeczeństwach demokratycznych może wiązać się ona z jednej strony z kryzysem demokracji - rozumianej jako wykorzystywanie tradycyjnych mechanizmów (np. głosowania w wyborach), a z drugiej rosnącą potrzebą obywateli do wywierania presji na rządzących i chęcią wpływu na procesy decyzyjne (Foryś, 2016, s. 48).

Cechą ruchu społecznego jest jego masowość przy jednoczesnej selektywności. Interakcje, w jakie wchodzą jednostki w jego ramach, są przelotne, nieformalne ale trwałe. Głównymi motywacjami są wspólne emocje, wartości i cele. Jednocześnie istotna jest identyfikacja z ruchem - świadomość uczestnictwa w nim. Ruch społeczny wiąże się z reakcją na funkcjonowanie państwa i społeczeństwa - w obszarach, gdzie instytucje czy organizacje publiczne zawodzą - objawiającą się w kontestacji dotychczasowego porządku. Dążenie do zmian jest oddolne, a zalążki ruchu formułują się na etapie analizy istniejącego porządku społecznego i postawienia diagnozy wiążącej się z postulatem wprowadzenia zmian lub zapobieżenia niekorzystnym zjawiskom. Ruchy społeczne przyjmują zatem charakter postępowy, stawiając sobie zadanie poprawy istniejącego stanu rzeczy przez wywołanie zmiany społecznej (istnieją też ruchy mające charakter zachowawczy stawiające sobie za cel utrzymania istniejącego status quo - są to zazwyczaj ruchy społeczne „starego” typu jak nacjonalistyczne czy rasistowskie) (Paleczny, 2010, s. 13-14; por. Ekstowicz, 2015, s. 48).

Ruchy mogą mieć różnoraki charakter - najczęściej wskazuje się tutaj na rewolucyjny lub reformatorski. Pierwsze dążą do obalenia istniejącego porządku, mając charakter całościowy, drugie mają na celu zmianę wybranych elementów rzeczywistości społecznej, dążąc do modyfikacji instytucji czy sposobu myślenia ludzi do własnych potrzeb (Paleczny, 2010, s. 15). W klasyfikacjach wyodrębnia się również: ruchy ekspresywne - niedążące do bezpośrednich zmian, ale przede wszystkim do rozpowszechniania swoich przekonań; ruchy walczące o prawa człowieka - mające na celu zagwarantowanie sprawiedliwości społecznej; ruchy walczące przeciwko ryzyku - kwestionujące decyzje na poziomie państwowym jako potencjalnie niebezpieczne społecznie (Ekstowicz, 2015, s. 51). 
Ruchy społeczne w swojej początkowej fazie mają charakter spontaniczny i nieformalny, gromadząc ludzi połączonych potrzebą zmiany i niezadowolenia z istniejącej sytuacji. Świadomość wspólnego celu i podejmowane działania prowadzą do sytuacji komunikacyjnych i wyłaniania się mechanizmów łączności, co pozwala na konsolidację i zwiększanie zasięgu ruchu. Uczestnictwo $w$ ruchu jest dobrowolne, a jego organizacja jest $\mathrm{z}$ zasady nieformalna i opiera się na komunikacji bezpośredniej - w trakcie spotkań, wieców czy demonstracji, co z czasem przeradza się w bardziej trwałe struktury komunikacyjne i organizacyjne. W miarę rozwoju ruchu mogą pojawiać się tendencje do jego formalizacji, tworzenia struktur przywódczych i instytucjonalizacji (Ekstowicz, 2015, s. 44; Paleczny, 2010, s. 15-16).

$\mathrm{Na}$ czele ruchu stają liderzy, którzy dzięki swej charyzmie są w stanie zainspirować i pociągnąć za sobą innych, zapewniając jednocześnie ciągłość funkcjonowania ruchu i powtarzalność pewnych działań (Paleczny, 2010, s. 17). W skład ruchu wchodzą również aktywiści - ideologicznie zorientowani rzecznicy danej sprawy, także zwolennicy ruchu oraz jego sympatycy (Paleczny, 2010, s. 19). Ruchy społeczne przyciągają także ekspertów, naukowców, artystów, pisarzy, specjalistów stanowiących ich zaplecze intelektualne ( $\mathrm{Pa}-$ leczny, 2010, s. 22).

W literaturze istnieje podział na „stare” i „nowe” ruchy społeczne, który nie jest ostry ani też rozłączny. „Nowe” ruchy mogą wyrastać na bazie „starych”, a ich cechą jest zazwyczaj postępowy charakter, innowacyjność, krytyka tradycji. Są to często ruchy odwołujące się do idei sprawiedliwości społecznej. Nowe ruchy społeczne wpisane są raczej w funkcjonowanie społeczeństw demokratycznych, podczas gdy stare łączą z kontestowaniem porządku związanego z nierównościami klasowymi, etnicznymi czy rasowymi w społeczeństwach autokratycznych czy totalitarnych. Są to ruchy mające swoją genezę w czasach po drugiej wojnie światowej. Innymi wyróżnikami nowych ruchów jest wychodzenie ponad arenę narodową, a także operowanie w strefie „kultury multimedialnej” (internetu czy łączności komórkowej - podczas gdy stare ruchy opierają się na słowie pisanym - manifestach, odezwach czy książkach) (Marczewska-Rytko, 2015, s. 44; Nowak, 2012, s. 4; Paleczny, 2010, s. 25-26).

Nowe ruchy społeczne rzadko mają charakter masowy. Obejmują bardziej specyficznych członków, chcących działać w ramach społeczeństwa obywatelskiego. Jednocześnie są to ruchy otwarte, uniwersalne, niekiedy ogólnoświatowe, przekraczają granice polityczne i kulturowe. Nie dążą też do przekształcania się w sformalizowane struktury, pozostając przy luźniejszych formach organizacyjnych i odwołując się do zasad solidaryzmu społecznego. Brak tutaj również wyraźnego jednoosobowego przywództwa, jak też ustalonej hierarchii. Nowe ruchy - w większej mierze niż stare - mają charakter altruistyczny. Podczas gdy stare ruchy kierują swoją uwagę w stronę zmian politycznych, ekonomicznych, nowe skupiają się na ochronie słabszych grup, przeciwdziałaniu dyskryminacji, ekologii, prawach mniejszości czy skutecznej dystrybucji dóbr. Członkowie ruchów społecznych rekrutują się zazwyczaj z klasy średniej, a udział osób z górnej lub dolnej części hierarchii społecznej jest w nich mniejszy (Marczewska-Rytko, 2015, s. 44; Nowak, 2012, s. 4; Nowosielski, 2011, s. 17; Paleczny, 2010, s. 26-28). 
Do najważniejszych funkcji nowych ruchów społecznych należą: diagnostyczna (analizująca i ujawniająca podłoże i mechanizmy stosunków społecznych), krytyczna (polegająca na kwestionowaniu porządku społecznego w danym zakresie), mobilizacyjna (polegająca na włączaniu do ruchu nowych uczestników, a więc uświadamianiu podobieństwa własnych poglądów jednostki do celów ruchu), prowokacyjna (pełnienie roli katalizatora zmian społecznych), konstruktywna (inaczej modernizacyjna, innowacyjna, polegająca na proponowaniu nowych rozwiązań i modeli rzeczywistości społecznej), ludyczna (prowadząca do nabywania przez uczestników umiejętności wspólnego spędzania czasu, wspólnej organizacji działań czy wreszcie - zabawy) (Paleczny, 2010, s. 31-35).

Warto zwrócić uwagę na poziom mikroanalizy ruchu społecznego - związany z funkcjonowaniem w nim jednostki. Istotna jest tutaj tożsamość jednostki, która wpływa na jej przystąpienie do danego ruchu. Podzielane z innymi elementy tożsamości skłaniają do skupiania się wokół pewnej idei, a jednocześnie przystąpienie do ruchu może kształtować tożsamość jednostki stającej się częścią tożsamości zbiorowej. Innym elementem skali mikro są predyspozycje psychiczne jednostki - zwłaszcza napięcia, jakie występują w związku z poczuciem deprywacji czy dysonansu związanych z odczuwaną niesprawiedliwością społeczną. Z udziałem w ruchu społecznym wiąże się również motywacja jednostki oraz interakcje między uczestnikami (Nowosielski, 2011, s. 22-23; por. Ekstowicz, 2015, s. 49).

Należy zwrócić też uwagę na rolę internetu (czy też szerzej nowych mediów umożliwiających komunikację) w funkcjonowaniu ruchów społecznych. Może on być wykorzystywany co najmniej dwojako. Po pierwsze, służy jako medium, za którego pomocą ruch może eksponować swoje idee docierając do członków ruchu i sympatyków, ale również do innych, potencjalnie zainteresowanych, osób. Po drugie, internet może być narzędziem mobilizacji służącym nie tylko werbowaniu nowych zwolenników, ale również doraźnemu informowaniu osób utożsamiających się z ruchem o podejmowanych działaniach. Internet służy również codziennej komunikacji członków ruchu - mającej różne formy (np. strony www, listy mailingowe, fora dyskusyjne) (por. Nowosielski, 2004, s. 169-171). Działalność w sieci bywa niekiedy wskazywana jako jeden z wyróżników nowych ruchów społecznych, wyróżniana jest również osobna kategoria ruchów społecznych działających w sieci (Marczewska-Rytko, 2015, s. 47; Nowak, 2012, s. 7-8). Usieciowienie aktywizmu pozwala na globalizację ruchów społecznych i ich transnarodowość, co przekłada się na powstawanie coraz gęstszej sieci powiązań opartych na infrastrukturze technicznej (Nowak, 2012, s. 8-9).

Warto również nawiązać do koncepcji Alaina Touraine, który definiuje ruchy społeczne jako „zorganizowane konflikty” (organized conflicts). Są one konfrontacją zorganizowanych aktorów na polu społecznego użycia wspólnych wartości kulturowych. Aktorzy dzielą te same wartości, jednak nie zgadzają się co do sposobu społecznego wykorzystania zasobów i orientacji kulturowych (Touraine, 2010, s. 90). Touraine (2004, s. 721) wskazuje, że możliwe jest zastosowanie tej definicji dla społeczeństw postindustrialnych opartych na informacji i komunikacji, a konflikty związane ze społecznym wykorzystaniem informacji są widoczne na takich polach, jak medycyna, edukacja czy mass media. 
Touraine (2004, s. 722-723) proponuje zmianę terminu „ruch społeczny” na „ruch kulturowy” (cultural movement) lub „historyczny” (historical movement) - rezerwując „ruch społeczny” dla konfliktów strukturalnych wynikających ze sporu wokół władzy socjoekonomicznej. W tym ujęciu transformacja społeczna czy przeorganizowanie sił społecznych nie znajduje się już w centrum uwagi, które zajmują „żądania moralne” - często związane z prawami człowieka i koncepcją ich uniwersalności.

Należy zauważyć, że kongres dobrze wpisuje się w definicje Touraine’a - jako grupa walcząca o prawa człowieka, której głównym orężem jest informacja, a celem wprowadzenie do społecznego obiegu prawnoczłowieczego modelu niepełnosprawności w miejsce medycznego. Konflikt w ogólnym zarysie przebiega na linii tych modeli i ma on charakter w dużej mierze informacyjny. Wiążą się z tym również działania komunikacyjne w internecie, których charakter wynika z obrotu informacją. Działania skupiają się tutaj nie na podważaniu struktury społecznej (jak w „klasycznych” ruchach), ale raczej na sporze wokół zarządzania historyczną zmianą paradygmatu myślenia o niepełnosprawności (por. Touraine, 2004, s. 723).

\section{WYNIKI}

Punktem wyjścia w wywiadach była rozmowa o tym, jak organizatorzy postrzegają znaczenie kongresu i konwentów dla środowiska niepełnosprawnościowego. Zagadnienie to nie wiąże się bezpośrednio z wirtualizacją, jednak pozwala pokazać charakter opisywanego zjawiska i lepiej zrozumieć zmiany, jakie zaszły po przeniesieniu go do sieci.

Jednym z ważnych aspektów, podkreślanych przez organizatorów, jest sam fakt spotkania. To jest taka impreza, na która się zawsze czeka. (...) dla środowiska jest to ważne wydarzenie - nie przez efekty, ale bardziej przez spotkanie (...). To, co się dzieje między nami, zawsze było najważniejsze (W1).

Kongres jest również miejscem wymiany informacji. Konwenty dostarczają okazji do rozmowy o problemach lokalnych - jest to spotkanie, podczas którego mówimy o tym, co się dzieje na naszym podwórku (W1). To jest miejsce, gdzie można wymienić swobodnie poglądy na temat obecnej sytuacji, tego, co może być chociażby za kilka lat, czy jak usprawnić pewne działania, które na przykład już sa wdrażane (W2). Kongres i konwenty to przede wszystkim źródło informacji na temat tego, co w systemie wsparcia działa, (...) co działa dobrze, (...) co nie działa, (...) czego w ogóle nie ma. (...) to jest taki probierz nastrojów (W6). Regionalność konwentów była wielokrotnie podkreślana i wydaje się stanowić znaczną wartość dla badanych osób - szczególnie w związku z możliwością uzyskiwania nowej unikatowej wiedzy związanej z lokalnymi działaniami. Podobnie kongres stanowił okazję do wymiany informacji, które nie zawsze pojawiają się w obiegu medialnym.

Jednocześnie zwracano uwagę na aspekt obywatelski kongresu i konwentów: jak ktoś się zaangażuje, to znaczy, że nie jest mu obojętna rzeczywistość (W1). Wskazywany był tym samym aktywizacyjny aspekt - związany z przyciąganiem nowych ludzi do idei kongresowych - zeby próbować zwiększyć jedność (...) mocno rozbitego środowiska (W3). Ważne jest tutaj również zjawisko sieciowania - wymiany kontaktów między uczestnikami. Dla 
wielu osób to była jedyna przestrzeń, w której mogli (...) nawiązać kontakt z osobami, których $w$ innych okolicznościach by nie poznali, a które (...) dotykają tych samych trudności, problemów (W8). Zwracano też uwagę na możliwość oddania (...) głosu różnym częściom środowiska (W5). Jednocześnie wskazywano na trudność w pozyskiwaniu osób, które mogłyby zostać liderami środowiska kongresowego. Jak skomentowała to jedna $\mathrm{z}$ badanych osób: trochę mamy krótka ławkę (W6).

Złożonym aspektem kongresu i konwentów jest ich rola polityczna. Jak ujęła to jedna z osób: przy kongresie (...) myślimy o tym, żeby być jak najdalej od polityki i żeby być neutralnym (...), z drugiej strony chcielibyśmy jak najbardziej wpływać na rzeczywistość. (...) fajnie, żeby to zmieniało świat (W1). Chęć wpływu na ustawodawstwo przejawia się w uchwałach kongresu i konwentów, które następnie są przedstawiane decydentom. Kongres jest postrzegany jako głos środowiska, które upomina się o przestrzeganie swoich praw (W4) i ma oddziaływać na zmiany prawne i na polityków (W5). Były wypracowywane rzeczy, postulaty, zmiany, które następnie były przepychane (W7). Uwidacznia się tutaj zatem reformatorski charakter kongresu, który za cel stawia sobie zmianę społeczną.

Do 2019 r. założeniem kongresu i konwentów było unikanie czynnych wystąpień polityków. Pojawiali się oni jako uczestnicy, brali udział w dyskusjach (jako „głos z sali”), jednak nie byli zapraszani do wygłaszania referatów czy uczestniczenia w panelach dyskusyjnych. Zabiegi te były podyktowane zakładaną apolitycznością kongresu, który zainteresowany jest raczej polityką publiczną (policy) niż polityką rozumianą jako pewnego rodzaju gra i próba sił (politics). Wyjątek został uczyniony w 2020 r., gdy w panelu dyskusyjnym pojawił się m.in. Pełnomocnik Rządu ds. Osób Niepełnosprawnych. Sytuacja ta była jednak podyktowana raczej tym, że należy on do środowiska niepełnosprawnościowego (którego jest wieloletnim działaczem), niż deklaracją sympatii politycznych kongresu, który nadal stara się utrzymać zasadę: od polityki jak najdalej (W4).

Konieczność wirtualizacji kongresu i konwentów spotkała się z bardzo różnymi opiniami respondentów - od krytycznych po bardzo pochlebne (włącznie z wyrażeniem chęci stałego przeniesienia jednego z konwentów do sieci). Pierwsze dobrze ilustruje wypowiedź: wiedzieliśmy, że to będzie forma, która nie będzie spełniała wymagań większości osób (W1), drugie: okazało się, że (...) to był hit (W4).

Jako jedną z głównych zalet wskazywano większą dostępność kongresu i konwentów. Jak wskazują organizatorzy - dużo łatwiej było zapraszać prelegentów. Na spotkaniach pojawiły się również osoby, które nie miałyby szansy dotrzeć na nie w formie stacjonarnej, np. ze względu na niepełnosprawność lub znaczną odległość od miejsca zamieszkania - każdy mógł (...) z domu (...) z różnych stron świata się z nami połączyć (W1). Okazało się, że (...) to był hit, mieliśmy wysoka frekwencje [na konwencie - ZG] (W4). Była okazja żeby połaczyły się osoby, które $z$ absolutnie obiektywnych przyczyn nie mogłyby się stawić na spotkaniu [stacjonarnym - ZG] (W8). Wskazywano też, że rejestracja nagrania z kongresu i konwentów potencjalnie zwiększała ich dostępność - można je było obejrzeć w sieci później. Nie ma jednak informacji, ile osób skorzystało z takiej opcji.

Organizacja kongresu i konwentów w trybie wirtualnym była widziana dwutorowo. Z jednej strony wskazywano na pewną jej łatwość związaną z brakiem poszukiwania znacznych środków na wynajem sal, catering czy materiały warsztatowe, a także łatwość 
polegającą na braku konieczności obsługi bezpośredniej uczestników. Szczególnie podkreślane były zdecydowanie niższe koszty - co jest bardzo istotne z punktu widzenia wydarzenia niemającego stałego źródła finansowania, a także łatwość organizacji związaną $\mathrm{z}$ brakiem konieczności wychodzenia $\mathrm{w}$ teren. $\mathrm{Z}$ drugiej jednak strony zwracano uwagę na nowe trudności techniczne i wyzwania $\mathrm{z}$ nimi związane - jak transmisja w mediach społecznościowych, zapewnienie tłumacza języka migowego łączącego się zdalnie, dodawanie napisów w czasie rzeczywistym. Wskazywano też, że czasochłonność organizacji wydarzeń nie była mniejsza niż w przypadku spotkań stacjonarnych.

Wirtualizacja wpłynęła również na pewne aspekty związane z samym przebiegiem spotkań. Podkreślano, że dyskusje były spokojniejsze niż zazwyczaj, co wynikało z ograniczonych możliwości wypowiedzi i zadawania pytań (zadawano je za pomocą czatu i wybierane były przez prowadzących do przekazania osobom debatującym). Sprawiło to, że dyskusja była ograniczona głównie do panelistów, a wiele wypowiedzi pisanych zostało pominiętych. Zwrócono jednak uwagę na pozytywną rolę czatu, który umożliwia zabranie głosu, [osobom - ZG] które (...) nie maja odwagi, żeby zabrać głos normalnie (W8).

Łatwiej było też panować nad czasem wypowiedzi i uporządkowaniem kolejnych elementów wydarzenia. Zwracano jednak uwagę, że dyskusja przebiegałaby inaczej gdyby ludzie patrzyli sobie w oczy i nie musieli mówić do laptopa (W1). Dyskusja zdalna była bardziej stonowana i mniej dynamiczna, ale czy to jest lepiej dla tego typu spotkań? - pyta retorycznie jeden z respondentów (W6).

W trakcie kongresu nie zdecydowano się na przygotowanie mniejszych spotkań dyskusyjnych (jakie odbywały się w formie stacjonarnej) - całe wydarzenie rozgrywało się na forum głównym, co sprawiało, że zabranie głosu w dyskusji lub zadanie pytania było trudniejsze niż zazwyczaj. Podobnie jak w przypadku wydarzeń stacjonarnych również i w tym roku odnotowano głosy radykalne, niekiedy łamiące zasady współżycia społecznego - wydaje się, że w tym aspekcie wirtualizacja nie wniosła istotnych zmian, z zaznaczeniem, że wypowiadano się za pomocą funkcji chata. Podkreślano jednak, że dyskusje były bardziej merytoryczne niż zazwyczaj (podniesiona została poprzeczka, jeśli chodzi o poziom dyskusji merytorycznej - W6), co jednak wynikało w dużej mierze z tego, że głos zabierali uczestnicy panelu - osoby doświadczone w publicznych wypowiedziach i dyskusjach.

Wirtualizacja wpłynęła nieco na zmianę charakteru konwentów regionalnych. Nadal miały one charakter lokalny, jednak stały się bardziej ogólnopolskie (W3) ze względu na brak bariery odległości. Wskazywano, że niekiedy regionalizm rozpływał się w kwestiach ogólnych - trudno coś regionalizować, jak organizujesz to zdalnie (W7).

Zarówno kongresy, jak i konwenty oceniono jako udane pod względem merytorycznym, głównie jednak za sprawą ciekawych panelistów (jak Pełnomocnik ds. Osób z Niepełnosprawnością, Doradca Prezydenta ds. Osób z Niepełnosprawnością).

Interesującym zjawiskiem była kwestia frekwencji. W wywiadach podkreślano możliwość dotarcia z transmisją online kongresu i konwentów do zdecydowanie większej liczby osób. Jednak o ile konwenty regionalne odnotowały podobną (a niekiedy nawet większą) jak we wcześniejszych latach liczbę uczestników (przedział 50-120 osób), to w przypadku kongresu spadła ona znacząco (ze średnio 400-500 uczestników w trybie stacjonarnym 
do około $100 \mathrm{w}$ warunkach wirtualnych). Jak zaznaczali organizatorzy - o ile potencjalna dostępność była większa, o tyle jest prawdopodobne, że wiele osób obawiało się kwestii technicznych i nie próbowało się łączyć lub też sobie z tym nie poradziło.

Jednak to nie w kwestiach technicznych upatrywano głównej przyczyny spadku frekwencji. Wskazywano na pewnego rodzaju rozmycie się odpowiedzialności organizacyjnej. Presja przygotowań do kongresu zdalnego była dużo mniejsza i w pewien sposób zabrakło mocy przerobowych (W3). Jak wskazywano - odpowiedzialność za wydarzenie stacjonarne jest dużo większa: ludzie się zjada, będzie kasa na to, trzeba to rozliczyć (W3). Wynajęcie sali, zapewnienie dostępności dla osób z różnymi niepełnosprawnościami, przygotowanie materiałów, organizacja cateringu - elementy nieodzowne w trakcie poprzednich lat - okazały się być pewnym motorem mobilizującym liderów do wzmożonego działania. Świadomość braku konieczności organizowania tych elementów sprawiła, że działania nie były tak dynamiczne jak zazwyczaj, a niektóre sprawy odkładane były na później jako łatwe do wykonania. Sprawiło to, że kongres był ogarniany na sam koniec (W3), kiedy już zbliżał się jego termin.

Zwrócono również uwagę na fakt, że kongres po raz pierwszy odbył się w weekend (sobota). Wskazywano to jako zaletę (mogłam chodzić ze słuchawkami i wykonywać inne czynności, nie musiałam jechać do Warszawy - W4), częściej jednak jako wadę ze względu na to, iż wiele osób prawdopodobnie zaplanowało na ten czas inne czynności (tłumaczono w ten sposób również mniejszą niż zazwyczaj frekwencję kadry urzędniczej oraz szeroko pojętej grupy „decydentów”, która na kongresie pojawiała się często w ramach obowiązków służbowych). Wśród możliwych przyczyn wskazywano mniejsze zainteresowanie tej grupy wydarzeniami online. Należy jednak zastanowić się, czy stan ten był faktycznie tym powodowany, czy też raczej może wynikał z ogólnej słabszej niż zazwyczaj promocji kongresu i konwentów. Zwraca uwagę fakt, że jeden z konwentów mógł pochwalić się wysoką frekwencją przedstawicieli administracji samorządowej. Jednak, jak wskazali organizatorzy - zostało włożone tutaj dużo pracy promocyjnej i sieciującej, a frekwencja była wynikiem zorganizowanych, często wieloletnich działań.

Wśród wad wirtualizacji wielokrotnie podkreślano problem braku możliwości spotkań kuluarowych. Spotkania indywidualne, często przypadkowe (gdzieś tam przy kawie - W1) stanowiły dla uczestników istotną wartość, której uzyskanie było niemożliwe w warunkach wirtualnych. Dla wielu ludzi ważny jest sam fakt wyjazdu na spotkanie - jada, spotykaja się, rozmawiaja (W5). Wirtualizacja sprawiła, że dyskusja odbywała się na poziomie (...) eksperckim (W2), co dla wielu osób nie było wystarczające. Mniej było elementów wymiany myśli między kilkoma osobami (W3). Wskazywano również na znaczenie spotkań kuluarowych dla kontaktów z lokalnymi urzędnikami i decydentami - byli oni dostępni na spotkaniach stacjonarnych i [pewne rzeczy - ZG] można było z nimi dograć uszczegółowić, ustalić (W6). Spodziewany brak spotkań kuluarowych mógł być również przyczyną spadku frekwencji na kongresie (żaden online nam tego nie zapewni - W8).

Zwracano również uwagę na ograniczone interakcje w trakcie głównych dyskusji. $\mathrm{Na}$ spotkaniu stacjonarnym szum [na sali - ZG] (...), mimika (W8) dają wypowiadającym się bezpośredni ogląd reakcji zgromadzonych osób. W trybie zdalnym możliwości te są znacznie ograniczone. Pewną przewagę miały osoby, które miały wcześniejsza znajomość 
tej grupy (W8), a więc „stali bywalcy” kongresu i konwentów, którzy nawet pomimo wyłączonych kamer wiedzieli, czego mogą się spodziewać rozpoznając znajome nazwiska.

$\mathrm{Z}$ prowadzonych wywiadów przebija pewna obawa o spadek rangi kongresu (mniejsza - o rangę konwentów). Wiąże się ona $\mathrm{z}$ ogólnym niższym zaangażowaniem ludzi $\mathrm{w}$ wydarzenia online, a także z pewną ich masowością (duży wybór wydarzeń online). Podkreślana jest różnica jakościowa w porównaniu $\mathrm{z}$ wydarzeniami stacjonarnymi - nie będzie pozytywnej energii, która napędzała to wydarzenie (...). To tak jak pójście na mecz (...) możesz go w telewizji obejrzeć - ale to nie to samo (W2). Wydarzenie nie będzie miało znaczenia takiego święta (W1). Jednocześnie wskazywano, że inne jest oddziaływanie medialne wydarzeń, które odbywają się na żywo - jeśli kilkaset osób zbiera się w jednym miejscu stacjonarnie i są tam osoby $\mathrm{z}$ ważnych organizacji, to widać, że to jest ważne (W3). Jak zauważa jeden z ekspertów: pomimo tego, że coraz mocniej funkcjonujemy (...) $w$ kontaktach wirtualnych to ranga tego wydarzenia jest mniejsza niż $w$ spotkaniach standardowych (...) [kongres może być - ZG] potraktowany jako jedno $z$ miliona spotkań online (W8).

Pojawiały się również refleksje odnoszące się do celów kongresu. Wskazywano tutaj zarówno cel społeczny - socjalizujący (spotkania na żywo - w tym spotkania kuluarowe), jak również funkcje związane $\mathrm{z}$ wypracowywaniem konkretnych propozycji (ze wskazaniem na III Kongres jako wzorcowy pod tym względem), które trafialy pod strzechy ministerialne (W3). W przypadku dalszej wirtualizacji Kongresu nastawienie na cel związany z wypracowywaniem postulatów wydaje się szczególnie ważne i prawdopodobnie mogłoby stać się celem głównym, zastępując cel związany z zaspokajaniem potrzeb interakcyjnych. Wyróżnienie działań Kongresu na tle innych przedsięwzięć środowiska niepełnosprawnościowego musiałoby mieć zwiazek ze skutecznościa (...), że z tego coś wynika, (...) [są - ZG] przełożenia na rozwiązania (...). Zbieramy postulaty i później te postulaty sq organizowane (...). To by się samo obroniło (W1). Jednocześnie pojawiły się postulaty lepszego celowania w potrzeby lokalnych społeczności (również przez większe skupienie się na ich głosie i propozycjach), co wiąże się z bardziej celowym doborem tematów na konwentach.

Wyrażano również obawy o możliwości przyciągania nowych osób do kongresu i konwentów - wskazując tutaj jednak na ogólną trudność w rekrutacji (zwłaszcza młodych osób) niezależną od wirtualizacji (chociaż ta może pogłębić te trudności).

Jednocześnie wskazywano, że o ile kongres może być w pewien sposób zagrożony dłuższą wirtualizacją, o tyle konwenty - ze względu na ich zainteresowanie sprawami lokalnymi, mają większe szanse utrzymania swojej pozycji jako spotkań, które potencjalnie mogą przyczyniać się do rozwiązania konkretnych problemów danej społeczności.

$\mathrm{W}$ momencie badania trudne było przewidzenie trybu, w jakim odbędzie się następny kongres i konwenty. Organizatorzy rozważali obie sytuacje wskazując ich mocne i słabe strony.

W przypadku, gdyby kongres i konwenty miały odbyć się wirtualnie zwracano uwagę na to, że trzeba by było poszukać form, które animuja bardziej komunikację (W1). Włączanie uczestników w dyskusje i umożliwianie interakcji to jedno z najważniejszych, zdaniem respondentów, wyzwań dla przyszłych spotkań wirtualnych, aczkolwiek wskazanie 
konkretnych rozwiązań było trudne (jednym była propozycja podziału na wirtualne pokoje i rozmowy w mniejszych grupach).

Należy tutaj zwrócić uwagę, że pewna nieformalna wirtualizacja działań kongresu i konwentów istniała już wcześniej. Dyskusje odbywające się na różnych forach internetowych, listach mailingowych czy spotkaniach zdalnych - mających charakter zatomizowany i często nieformalny - znajdowały w wielu przypadkach finał w czasie spotkania kongresowego lub konwentowego.

Jakkolwiek badani liderzy wskazywali w większości na zdecydowaną chęć powrotu do formy stacjonarnej spotkań, to jednak zaznaczali, że od „onlinowości” nie uciekniemy (...), gro nawyków zdalnych zostanie (...) i to jest nieuniknione (W2). Wskazywano tutaj na atrakcyjność formy hybrydowej - spotkania stacjonarnego z transmisją online mającą możliwość zapewnienia udziału osobom, które nie są w stanie dojechać na wyznaczone miejsce.

\section{WNIOSKI}

Kongres aspiruje do bycia jednym z najważniejszych wydarzeń merytorycznych związanych z niepełnosprawnością w Polsce. Jego powstanie i działalność przypomina funkcjonowanie ruchu społecznego, należy jednak rozważyć różne aspekty tego zjawiska.

Cechami, które wskazują na przynależność definicyjną Kongresu do kategorii ruchu społecznego są jego obywatelskość, dobrowolne uczestnictwo, działanie nieinstytucjonalne, rozproszone przywództwo (opierające się na liderach), trwałe - chociaż niekiedy powierzchowne - relacje między uczestnikami. Kongres swoimi działaniami wpisuje się $\mathrm{w}$ reformatorski typ ruchu. Jego działania są powtarzalne (przybierając niekiedy tryb ciągły - związany z organizacją lub wypracowywaniem dokumentów programowych).

Uczestników i sympatyków Kongresu łączy też wspólny cel, jakim jest stworzenie możliwie najlepszych warunków do prowadzenia niezależnego życia (zgodnie z KPON) przez osoby z niepełnosprawnościami. Należy zwrócić tutaj uwagę, że o ile panuje zgodność co do celu ogólnego, to jego realizacja może być różnie widziana przez poszczególne grupy osób pojawiające się na kongresie oraz konwentach i uczestniczące w ich pracach wymaga to jednak dalszych pogłębionych badań, a analiza tego nie jest celem niniejszego opracowania.

Przebadana grupa osób jest zbyt mała, aby możliwe było wskazanie istotnej jakościowej różnicy w podejściu do idei kongresu i konwentów przez osoby z i bez niepełnosprawności. W dalszych badaniach (być może ilościowych i dotyczących innych, niż liderów, osób) należałoby zwrócić uwagę na ten aspekt - uwzględniając również osobną kategorię, jaką są rodzice osób z niepełnosprawnościami. Pozwoliłoby to na zniuansowanie panoramy społecznej kongresu i konwentów przez wskazanie zróżnicowania poglądów poszczególnych grup, jak również elementów je łączących.

Kongres swoim charakterem nawiązuje do definicji nowego ruchu społecznego. Objawia się to w wyraźnym podkreślaniu wagi kwestii sprawiedliwości społecznej i ochrony grup defaworyzowanych. Kongres postuluje wciąż jeszcze nowe w Polsce rozumienie 
niepełnosprawności oparte o jej model społeczny i prawnoczłowieczy, co stanowi podejście innowacyjne wynikające w pewnej mierze z krytyki starego „medycznego” porządku. Jednocześnie spełnia on założenia KPON, mówiące o zaangażowaniu osób z niepełnosprawnościami w sprawy ich dotyczące za pośrednictwem reprezentujących je organizacji (KPON, art. 4, p. 3; por. Kubicki, 2016, s. 96).

Kongres pełni też wiele funkcji przypisywanych ruchom społecznym: diagnostyczną (analiza sytuacji osób z niepełnosprawnościami w Polsce), krytyczną (kwestionowanie barier wynikających z potocznego rozumienia niepełnosprawności w jej modelu medycznym), mobilizacyjną (poszukiwanie nowych zwolenników idei), prowokacyjną (działania lobbingowe na rzecz wdrażania konkretnych rozwiązań w politykach publicznych), konstruktywną (proponowanie nowych - w skali Polski - rozwiązań), ludyczną (realizacja potrzeby spotykania się i przebywania ze sobą uczestników). Zakresy tych funkcji wydają się być różne - wymaga to jednak pogłębionych badań. Podobnie badań wymagają kwestie związane z poziomem mikroanalizy ruchu społecznego - tożsamością jednostek zaangażowanych w Kongres i kształtowaniem tożsamości zbiorowej.

Wydaje się, że pomimo licznych czynników wskazujących na możliwość zakwalifikowania definicyjnego kongresu do kategorii nowych ruchów społecznych, należy jednak powstrzymać się z jednoznacznym osądem, na co składają się co najmniej dwie przyczyny. Po pierwsze, Kongres nadal nie ma dużego zasięgu oddziaływania i skupia stosunkowo mało uczestników. Kilkadziesiąt do stu kilkudziesięciu osób na konwentach i kilkaset osób (chociaż w 2020 roku mniej) na Kongresie daje sumę około 1000 zaangażowanych osób. Nawet przy przytoczonym wcześniej założeniu, że nowe ruchy społeczne są zazwyczaj mniej liczne, wydaje się, że jest to nadal relatywnie zbyt mała grupa osób, aby bez zastrzeżeń nazwać ją ruchem (co ciekawe - osoby biorące udział w wywiadach nie użyły tego określenia ani razu). Po drugie, co wiąże się z zasięgiem oddziaływania, należy zauważyć, że chociaż na spotkaniach pojawiają się liderzy i przedstawiciele wielu różnych grup to jednak Kongres zapewne nie reprezentuje całego środowiska osób z niepełnosprawnościami, ani też jego większości.

Wydaje się, że na obecnym etapie Kongres stanowi raczej zalążek pewnego nurtu w środowisku, który propaguje idee wywodzące się z KPON, a który ma szansę przekształcić się w ruch pod warunkiem pewnego jego umasowienia oraz zapewnienia większej ciągłości działań. Jednocześnie prawdopodobnie nigdy nie stanie się wspólną reprezentacją osób z niepełnosprawnościami w Polsce, a raczej będzie ruchem „za niezależnym życiem", jako jedną z opcji w podejściu do niepełnosprawności. Należy również wskazać, że niektórzy badacze widzą ruch niepełnosprawnościowy (disability movement) jako oparty przede wszystkim na organizowaniu się osób z niepełnosprawnościami - z ograniczoną rolą osób bez niepełnosprawności jako wspierających sympatyków-sojuszników ruchu - w myśl zasady „nic o nas bez nas” (Campbell, Oliver, 2006, s. 22, 58-59). W tym kontekście kongres, organizowany w dużej mierze przez osoby bez niepełnosprawności i mający wciąż niewielkie grono uczestników i sympatyków, ma potencjalnie do przebycia jeszcze długą drogę, aby uzyskać miano ruchu społecznego - aczkolwiek należy podkreślić, że sukcesywnie zmierza do zwiększania liczby osób z niepełnosprawnościami w swoich szeregach. 
O ile nowe media, w tym szczególnie internet, uznawane są za sprzyjające działaniom obywatelskim, o tyle wydaje się, że przymusowa wirtualizacja sprawiła pewien kłopot - zarówno organizatorom jak i uczestnikom Kongresu. W dużej mierze spłaszczyła funkcję kongresu i konwentów do warstwy informacyjnej, redukując znacznie aspekt społeczny, który jest równie ważny - zwłaszcza że kontakty bezpośrednie wydają się być głównym katalizatorem powstawania tkanki społecznej prawie każdego ruchu.

Wydaje się również, że ranga kongresu (mniej - konwentów) została faktycznie osłabiona. Wyraża się to zarówno w mniejszej niż zazwyczaj frekwencji, ale także w prawdopodobnie mniejszym (co nie znaczy, że niskim) nakładzie pracy włożonej w przygotowania. Warto tutaj zauważyć, że organizacja odbywała się w cieniu pandemii i lockdownu, co z całą pewnością nałożyło się na możliwości, postawy i zasoby organizatorów. Forma wirtualna tak dużego przedsięwzięcia stanowiła pewnego rodzaju eksperyment (chociaż przymusowy), którego wynik siłą rzeczy nie mógł zostać przewidziany z góry. Należy jednak przypuszczać, że dalsza wirtualizacja kongresu i konwentów - nawet prowadzona w bardziej atrakcyjnej formule - może zaważyć na ich osłabieniu ze względu na rozluźnienie więzi (nawet jeżeli niekiedy powierzchownych) między uczestnikami. Jednocześnie szansą na zwiększenie potencjału wydaje się być forma hybrydowa $\mathrm{w}$ formule spotkań na żywo - transmitowanych w internecie (z możliwością zdalnych wypowiedzi i zadawania pytań).

Jednak niezależnie od przyszłej wirtualizacji lub nie - do organizatorów należy decyzja odnosząca się do celów i sposobu działania kongresu i konwentów: czy pozostaną one imprezą cykliczną, spotkaniem środowiska niepełnosprawnościowego, wydającą uchwały mające charakter raczej kurtuazyjny o krótkiej żywotności, czy też przekształcą się w działania zmierzające do wypracowywania konkretnych mechanizmów rozwiązywania problemów osób z niepełnosprawnościami (na miarę III Kongresu), które - przedkładane różnym osobom i instytucjom - zwiększą szanse na realny wpływ na polityki publiczne wobec tej grupy. Być może decyzja ta zaważy na tym, czy Kongres stanie się ruchem społecznym $\mathrm{w}$ pełnym tego terminu znaczeniu, czy pozostanie jedną $\mathrm{z}$ imprez integrujących część środowiska. Należy przy tym podkreślić, że realizacja celów Kongresu jest tutaj nadrzędna, a jego kwalifikacja definicyjna do kategorii ruchów społecznych - jeśli nastąpi - będzie miała charakter uboczny wynikający z charakteru i sposobu jego działania. Możliwe również, że do realizacji swoich celów Kongres nie potrzebuje umasowienia, a praca liderów, prowadzących odpowiednie działania i lobbing, jest wystarczająca do wpływania na legislację i wprowadzania zmian społecznych.

Kongres, jako zjawisko społeczne, wymaga dalszych pogłębionych badań. Perspektywa ruchu społecznego wydaje się być tutaj uzasadniona i warta rozszerzenia. Szczególnie interesujące wydaje się jej ujęcie w kategoriach proponowanych przez Touraine’a (2002) jako pewnego ruchu historycznego opartego o działania komunikacyjne i dążącego do wprowadzenia nowego paradygmatu niepełnosprawności. Interesujące może być również dalsze badanie wirtualnych działań Kongresu - niezależnie od tego, czy w kolejnym roku pozostanie on całkowicie w sieci, czy też - obok formy stacjonarnej - podejmie równolegle działania wirtualne. 


\section{BIBLIOGRAFIA}

Campbell, J., Oliver, M. (2006). Disability politics. Understanding Our Past, Changing Our Future. Routledge.

Ekstowicz, B. (2015). Procesy i ruchy społeczne w świecie na przełomie XX i XXI wieku. Civitas Hominibus: rocznik filozoficzno-społeczny, 10, 45-55.

Foryś, G. (2016). Ruchy społeczne. Pomiędzy oporem i opozycją? Polityka i Społeczeństwo, 1(14), 47-55. https://doi.org/10.15584/polispol.2016.1.5

Konecki, K. (2000). Studia z metodologii badań jakościowych. Teoria ugruntowana. Wydawnictwo Naukowe PWN.

Kongres III. (2017). Założenia dla projektów ustaw dla Nowego Systemu Wsparcia osób z niepełnosprawnościami. https://www.rpo.gov.pl/sites/default/files/III\%20Kongres\%20 ON\%20-\%20Za\%C5\%82o\%C5\%BCenia\%20dla\%20projekt\%C3\%B3w\%20ustaw\%20 dla\%20Nowego\%20Systemu\%20Wsparcia\%20os\%C3\%B3b\%20z\%20niepe\%C5\%82nosprawno\%C5\%9Bciami\%20v2.0\%202017.10.23.pdf

Konwencja o Prawach Osób Niepełnosprawnych (KPON 2012), sporządzona w Nowym Jorku dnia 13 grudnia 2006 r. (Dz.U. 2012, poz. 1169).

Kubicki, P. (2016). Środowiska osób z niepełnosprawnościami wobec polityki publicznej - studia przypadków. Studia z Polityki Publicznej, 3(1(9)), 95-110. https://doi. org/10.33119/KSzPP.2016.1.3

Malendowicz, P. (2016). Ruchy społeczne i myśl polityczna - co, jak i po co badać? Polityka i Społeczeństwo, 4(14), 5-18. https://doi.org/10.15584/polispol.2016.4.1

Marczewska-Rytko, M. (2015). Kategoria nowych ruchów społecznych w ujęciu Manuela Castellsa. Annales Universitatis Mariae Curie-Skłodowska Lublin - Polonia, XXII(2, SECTIO K), 43-53. https://doi.org/10.1515/curie-2015-0033

Nowak, J. (2012). Globalne usieciowienie aktywizmu: Nowe media a rozwój nowych ruchów społecznych. Kultura i Historia, 21, 2-24.

Nowosielski, M. (2004). Ruchy społeczne w Internecie. W: Lesław H. Haber (red.), Społeczeństwo informacyjne - Wizja czy rzeczywistość?: II ogólnopolska konferencja naukowa [Kraków, 30 maja 2003 r.: Fragmenty] (T. II , s. 167-173). https://winntbg.bg.agh.edu.pl/ skrypty2/0096/167-173.pdf

Nowosielski, M. (2011). Socjologiczna refleksja na temat ruchów społecznych. Przegląd Zachodni, 4, 3-28.

Paleczny, T. (2010). Nowe ruchy społeczne. Wydawnictwo Uniwersytetu Jagiellońskiego.

Touraine, A. (2002). The importance of Social Movements. Social Movements Studies, 1(1), 89-95. https://doi.org/10.1080/14742830120118918

Touraine, A. (2004). On the Frontier of Social Movements. Current Sociology, 52(4), 717-725. https://doi.org/10.1177/0011392104043498

Touraine, A. (2010). Samotworzenie się społeczeństwa. Zakład Wydawniczy NOMOS. 